\title{
7\% EFFECT OF PIT LATRINES ON HAND DUG- WELL WATER QUALITY - A CASE STUDY OF IJERO- EKITI COMMUNITY IN EKITI STATE, NIGERIA
}

\author{
Fadiji A.E ${ }^{1}$, Omomowo I.O ${ }^{2}$, Adebayo P.A ${ }^{3}$, Omomowo I.O ${ }^{4}$, Awogbami $\mathrm{S}^{5}$ \\ E-Mail Id: ayomidefadiji@gmail.com \\ ${ }^{1,2}$ Department of Pure and Applied Biology, Ladoke Akintola University of Technology, P.M.B 4000, \\ Ogbomoso, Oyo State \\ ${ }^{3,5}$ College of Health Science and Technology, Ijero-Ekiti, Ekiti State \\ ${ }^{4}$ Department of Microbiology, University of Maiduguri, Maiduguri, Borno State
}

\begin{abstract}
Water samples were taken from 6 private hand dug wells sited at major locations within the community. The samples were assessed for both the bacteriological and physicochemical parameters. Water quality parameters: $\mathrm{pH}$, chloride, nitrate, ammonium, electrical conductivity, turbidity, Iron, Phosphate, sulphate, conductivity, total dissolved solids, total acidity and total alkalinity were determined using standard methods. Faecal coliform, Heterotrophic, Vibrio and Salmonella spp. counts were determined by standard methods. All the physico-chemical parameters analyzed (except turbidity and nitrate) fell within the WHO and EPA standards for drinking water having a p-value of 0.05 .The bacteriological analyses, however, showed that the total heterotrophic count ranged from $1.3 \times 10^{6}-1.5 \times 10^{7} \mathrm{cfu} / \mathrm{ml}$, the highest coliform count was $3.6 \times 10^{6} \mathrm{cfu} / \mathrm{ml}$, highest Salmonella-Shigella counts was $6.3 \times 10^{3} \mathrm{cfu} / \mathrm{ml}$ ) and Highest E. coli count was $\left.2.8 \times 10^{4} \mathrm{cfu} / \mathrm{ml}\right)$. The bacteria isolated from water samples in this work included Escherichia coli, Enterobacter aerogenes, Pseudomonas spp, Staphylococcus aureus, Salmonella typhosa, Shigella spp, Vibrio cholerae, Proteus spp, Klebsiella spp. with Salmonella sp. However, Shigella and V. cholera were only isolated from A, B, D, E samples. Epidemiological data revealed that the reported cases in clinics of water borne diseases like diarrhea and typhoid fever were high, showing infections through consumption of contaminated water from the hang-dug wells. The presence of these biological indicators suggest that the water is potentially harmful to human health if consumed untreated. This study revealed that he presence of these biological indicators suggest that the water is potentially harmful to human health if consumed untreated. Appropriate awareness and local institutional capacity building through provision of well-protected latrines, piped water and sustainable sanitation to reduce potential risk to public health is therefore advocated.
\end{abstract}

Keywords: Physicochemical, Epidemiological, Indicators, Bacteriological.

\section{INTRODUCTION}

Water is one of the basic necessities for the sustenance of life, and it impacts nearly all areas of life. Water quality and the risk to waterborne diseases are critical public health concerns in many developing countries. Today, close to a billion people mostly living in the developing world do not have access to safe and adequate water (UNICEF/WHO, 2012). The World Health Organization (WHO) estimates that around 94\% of the global diarrheal burden and $10 \%$ of the total disease burden are due to unsafe drinking water, inadequate sanitation, and poor hygienic practices (Fewtrell et al., 2007).

Groundwater is generally considered to be of good quality, hence, in many parts of the world it is a preferred source for water supply, irrigation and industrial purposes. Due to its proximity to the surface and the low cost of utilization, groundwater obtained from springs and wells continues to be particularly attractive as a source of water supply. With increasing population, there is an increasing demand for more water. This in turn results in increased abstraction and, hence a strain on groundwater resources. Increased consumption of water also results in the generation of waste, such as human and industrial waste. Worldwide groundwater is being consumed in increasing quantities, and is also becoming increasingly affected by waste that is continuously discharged into the ground (Drangert and Cronin, 2004). Contamination issues are also a continental concern. In Africa, groundwater is increasingly being threatened by human activities (Xu and Usher, 2006). One of the major challenges of protecting groundwater resources in rural areas is, therefore, preventing contamination by human waste. This can be achieved through the provision and maintenance of appropriate and environmentally friendly waste disposal facilities. Providing safe drinking water is therefore related to providing appropriate sanitation and cannot be seen in isolation. These two elements are closely intertwined. Whenever providing clean water and appropriate waste disposal are not addressed simultaneously, it is very likely that a detrimental effect on human welfare may occur. Provision of these two services is also considered a measure of human welfare. The Millennium Development Goal (MDG) by 2015 


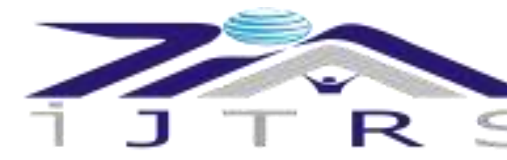

\section{International Journal of Technical Research \& Science}

halved the proportion of people without sustainable access to safe drinking water and basic sanitation (UNICEF, 2006).

Groundwater pollution has been the focus of attention by many researchers in recent times (Ayanlaja et al., 2005; Pritchard et al., 2007). Leachate from pit latrines is one of the major sources of water pollution. It is partly responsible for low access to potable water and sanitation problem especially in many developing countries (WHO, 2002). Pit latrine is a common method of excreta disposal in the developing world. It is popular and widely used in urban slums as well as rural areas probably because it is the simplest, cheapest and the most efficient excreta disposal method that is within the reach of poor people.

Ijero-Ekiti is a fast growing town in Ekiti State. Pipe-borne water supply is unreliable and residents in the town depend on dug-wells (shallow wells) for their main source of domestic water supply. The dug- wells are mostly constructed in the various homes and are usually accessed by the general public. The predominant form of excreta disposal in the community is the traditional pit latrine with a few septic tanks in some homes. The proximity coupled with the geographical location of most of these pit latrines/septic tanks to dug-wells raises concerns of possible groundwater pollution, which could consequently lead to waterborne diseases and possible outbreak of epidemics.

One of the major contributing factors of groundwater pollution is pit latrine mostly located near water sources such as shallow wells and boreholes. In fact, pit latrines have been identified as the major source of contamination of wells with faecal matter (Haword et al., 2007; Ayanlaja et al., 2005; Pritchard et al., 2007). Therefore, there is urgent need to provide an improved water supply and a safe means of excreta disposal.

\section{MATERIALS AND METHODS}

\subsection{Study Area}

Ijero Ekiti is a town in Ekiti State of Nigeria in West Africa. "Ijero Ekiti" refers to a common thought or mutual understanding which is situated in the northwest part of Ekiti State. Ijero Ekiti is the headquarters of Ijero Local Government. Ijero Ekiti coordinates in the north by 07.42.61 degree, east 00517.9 degree and her elevation is 1332 . With a population of 222,000 people as it was shown with the 2007 population census, Ijero Ekiti is the second largest town in the whole of Ekiti State. The Ijero local government has a largely agrarian population producing cash crops such as cocoa, kola nuts, coffee, kola, cashew, and timber. She also produces food crops such as yam, cocoyam, cassava, pepper, tomatoes, and banana. and all crops mentioned above are produced in large quantities with good qualities. Ijero Ekiti is also the seat of mineral resources such as tourmaline, colombat, vesper, and crystal stone.

\subsection{Sampling Sites}

Ijero-Ekiti community where sampling was carried out is the Headquarters of Ijero Local Government in Ekiti State. Hand dug-wells were selected from different areas within the community while WHO and EPA standards were used in assessing nthe quality of the water in community.

\subsection{Field Measurements}

The distances between the dug-wells and the nearest pit latrines were measured using a steel tape. Visual inspection of the hand dug-wells, sanitation systems and their immediate environs was conducted around each of the selected dug-wells.

\subsection{Sample Collection}

Monthly water samples were collected from June to August, 2016. The samples were collected in pre-washed and sterilised $500 \mathrm{ml}$ screw-capped bottles. The collected samples were then transported in ice-cold containers to the Microbiology laboratory of the department of Pure and Applied Biology of the institution for analysis.

\subsection{Determination of Physico-Chemical Parameters}

\subsubsection{Temperature}

The temperature of the water samples was taken in-situ with the use of digital thermometer. The thermometer was inserted in all the samples to know their various temperatures. Temperature was measured immediately the water was collected and recorded.

\subsubsection{The $\mathbf{p H}$}

The $\mathrm{pH}$ of the water samples was determined using the $\mathrm{pH}$ meter which consists of the electrode. $100 \mathrm{ml}$ of each sample was measured into $500 \mathrm{ml}$ beaker. The electrode of the $\mathrm{pH}$ meter was immersed in the water samples. The reading on the $\mathrm{pH}$ meter was recorded after 2 minutes when the reading was stabilised.

\subsubsection{Turbidity}

Turbidity of the water samples was determined using the 200P Turbid meter. Twenty-five (25) ml of each water sample was measured into the cell in the Turbid meter. The cell was then fixed into the Turbidimeter and covered. The button was then pressed and after stabilization, the value was recorded in Nephlometric Turbidity Units (NTU).

$$
\begin{aligned}
& \text { www.ijtrs.com } \\
& \text { www.ijtrs.org }
\end{aligned}
$$




\subsubsection{Nitrite}

ILosvay's reagents number one and number two were used in the determination of the nitrite levels. Fifty (50) ml of each water sample was measured into a beaker. Two (2) $\mathrm{ml}$ each of the reagents (number one and two) were measured and added to the water samples. It was then allowed to stand for 15 minutes. The appearance of a pinkish colour development in the samples showed that there is the presence of nitrite. After the colour development, the Lovibond comparacter with a nitrite disc in it is then read to match colour. The value recorded with the colour match was then converted to $\mathrm{ml} / \mathrm{l}$ by multiplying the value by 0.02 .

\subsubsection{Nitrate}

The Palintest Nitratest method was used in the determination of the nitrate levels of the water samples. The nitrate tube was filled with $20 \mathrm{ml}$ each of the water samples. One level spoonful of Nitratest Powder and one Nitratest tablet was added to the water samples. The screw cap was replaced and the tube shook for about one minute and later gently inverted three times to aid flocculation. The tube was allowed to stand for two minutes to ensure complete settlement. The screw cap was then removed and the top of the tube wiped with a clean tissue. The clear solution was carefully decanted into a round test tube, filling to the $10 \mathrm{ml}$ mark. One Nitricol tablet was then added crushed and mixed to dissolve. It was then allowed to stand for about 10 minutes to allow full colour development. A wavelength of $570 \mathrm{~nm}$ on the Palintest Photometer was selected and the reading recorded. The Nitratest calibration chart was then consulted for the values.

\subsubsection{Ammonia}

The Palintest Ammonia test is based on the Indophenol method. The test tube was filled with each of the sample to the $10 \mathrm{ml}$ mark. One Ammonia number one tablet and Ammonia number two tablet was added, crushed and mixed to dissolve. It was allowed to stand for 10 minutes to allow colour development. A wavelength of $640 \mathrm{~nm}$ was then selected on the photometer. The photometer reading was recorded and then the ammonia calibration chart consulted for the values.

\subsubsection{Phosphate}

A test tube was filled with $10 \mathrm{ml}$ of the water samples. One phosphate High Range tablet was crushed and mixed to dissolve. This was allowed to stand for about 10 minutes to allow for full colour development. A wavelength of 490 nm was selected on the photometer and readings taken.

\subsubsection{Determination of Colour}

Colour was determined by visual comparism using Lovibond colour disc (Pt-Co).The disc consist of different colours which is graduated. Sample was placed on disc and observed to see colour changes, and then the reading was taken for the colour which it corresponds with (US-EPA, 1983; ARHA-AWWA-WPCF, 1985; Trivedy and Goel, 1986).

\subsubsection{Determination of Odour}

Sample was introduced into a bottle that has been rinsed with $4 \mathrm{M} \mathrm{HCl}$ and distilled water. A stopper was inserted in the bottle and shaken for 2 or 3 seconds. The stopper was removed and quickly the odour was observed by putting the nostrils near the mouth of the bottle (WHO, 1985; Nsi, 2007).

\subsubsection{Determination of Conductivity}

A conductivity meter was used .The conductivity cell was calibrated with the standard $\mathrm{KCl}$ solution. The sample was brought to room temperature. The conductivity cell was washed with portion of the sample and then filled completely with the sample ensuring there was no air bubble adhered to the electrode and reading taken. The results were expressed as micro siemens per centimeter $(\mu \mathrm{S} / \mathrm{cm})$ (US - EPA, 1983; APHA - AWWA - WPCF, 1985; Trivedy and Goel, 1986; NWRI, 2001).

\subsubsection{Determination of Total Hardness}

The EDTA titration method was used in determining the total hardness of the samples. The sample was shaken thoroughly. $25 \mathrm{~cm}^{3}$ of the sample was taken and diluted with $50 \mathrm{~cm}^{3}$ of distilled water and transferred quantitatively into a clean $250 \mathrm{~cm}^{3}$ Elemeyer flask. $2 \mathrm{~cm}^{3}$ of buffer solution $\left(\mathrm{NH}_{4} \mathrm{CL}-\mathrm{NH}_{4} \mathrm{OH}\right)$ was added, followed by two drops of Eriochrome Black indicator and the sample titrated with standard EDTA solution that has been standardized using the standard calcium solution. The formation of blue colour indicated the end point, titre value was recorded. (USEPA, 1983; APHA-AWWA-WPCF, 1985; Trivedy and Goel, 1986; NWRI, 2001)

\subsubsection{Determination of Total Dissolved Solids}

$100 \mathrm{ml}$ of the sample was quantitatively transferred into an evaporating dish that has been previously weighed and dried in an oven for one hour and cooled in desiccators. The content of the dish was evaporated to dryness on a

$$
\begin{aligned}
& \text { www.ijtrs.com } \\
& \text { www.ijtrs.org }
\end{aligned}
$$




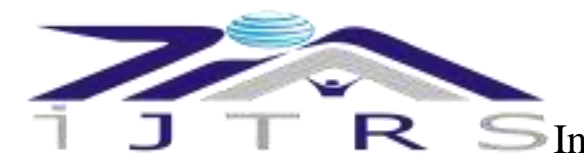

International Journal of Technical Research \& Science

water-bath to a constant weight. The residue was dried in an oven between 103-105oC for two hours, cooled in a desiccators and the difference in weight calculated (US-EPA, 1983; APHA-AWWA-WPCF, 1985; Trivedy and Goel, 1986; NWRI, 2001).

\subsubsection{Determination of Suspended Solids}

A $20 \mathrm{~cm} 3$ of well-mixed water sample was filtered through Gooch funnel under slight suction ensuring all solids were transferred, the residue was washed three times with about $5-10 \mathrm{~cm}^{3}$ of water allowing to drain free from water after each wash. The residue was placed on a watch glass and dried in an oven at $105{ }^{\circ} \mathrm{C}$ for one hour. It was then allowed to cool in a dessicator and its constant weight was taken. Weight of the filter was subtracted to obtain the weight of the suspended solids (Nsi, 2007).

\subsubsection{Determination of Chemical Oxygen Demand (COD)}

$20 \mathrm{~cm}^{3}$ of sample was placed in a $500 \mathrm{~cm}^{3}$ refluxing flask. $10 \mathrm{~cm}^{3}$ of standard $\mathrm{K}_{2} \mathrm{Cr}_{2} \mathrm{O}_{7}$ with several glass beads

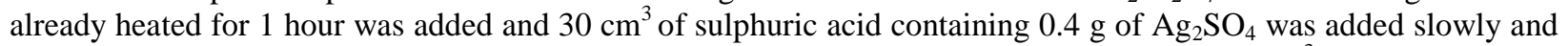
mixed to dissolve $\mathrm{Ag}_{2} \mathrm{SO}_{4}$. It was then refluxed for 1hour.It was cooled and diluted with $150 \mathrm{~cm}^{3}$ of distilled water, the mixture was titrated against standard ferrous ammonium sulphate (FAS) using $0.15 \mathrm{~cm}^{3}$ ferrion indicator. Reflux of blank containing the reagents was also titrated as above (Nsi, 2007).

\subsubsection{Determination of Dissolved Oxygen and Biochemical Oxygen Demand}

The Azide modification of the Winkler's method was used to determine DO and BOD. $250 \mathrm{~cm}^{3}$ of the sample was introduced into a stopped dark bottle and $2 \mathrm{~cm}^{3}$ of manganese sulphate solution and $2 \mathrm{~cm}^{3}$ alkali-iodide-azide reagent was added and mixed by inverting the bottle several times. Then $5 \mathrm{~cm} 3 \mathrm{of} \mathrm{H}_{2} \mathrm{SO}_{4}$ was added immediately precipitate settled. The bottle was then shaken to ensure distribution of iodine. $25 \mathrm{~cm}^{3}$ of the mixture was taken into a conical flask and titrated against $0.01 \mathrm{M}$ sodium thiosulphate, until titrand changed to pale-straw colour. $5 \mathrm{~cm}^{3}$ of starch indicator was then added to it and the titration continued until first disappearance of the blue colour. The titration was carried out three times and average titre value was noted as dissolved oxygen (DO).

A fresh sample was incubated at $20{ }^{\circ} \mathrm{C}$ for 5 days and the above procedure repeated with it. The difference between DO for incubated sample and DO not incubated was determined (US-EPA, 1983; APHA - AWWA - WPCF, 1985).

\subsection{BACTERIOLOGICAL ANALYSES}

\subsubsection{Microbial Analysis of the Water Sample}

The microbial analysis was performed to determine the microbiological quality of the water sample. These tests which include the total viable counts, i.e., the total mesophilic bacteria count, and the estimation of the most probable number (MPN) of faecal coliform bacteria were conducted on the water sample.

\subsubsection{Total Mesophilic Bacteria Count}

10 -fold serial dilution of the water sample was made before plating using the methods given by Amadi and Ayogu (2005). Using a sterile syringe $9 \mathrm{mls}$ each of the diluents (sterile water) was placed into 10 different test-tubes arranged in a rack. The water sample was then shaked to mix and $1 \mathrm{ml}$ was taken using sterile $5 \mathrm{ml}$ syringe and then added into the first test tube in the rack and shaken properly to mix. $1 \mathrm{ml}$ of the water was taken from the first test tube and delivered into the second test tube and mixed. This process was repeated for the 10-test tubes. $0.1 \mathrm{ml}$ aliquot of each dilution 1 to 5 test tubes was then plated on an already solidified nutrient agar. The water sample was spread evenly on the surface of the agar using sterile swab stick, after which the inoculated media was allowed to dry and then incubated at $37{ }^{\circ} \mathrm{C}$ for 24 hours (Amadi and Ayogu, 2005). After the incubation period, number of colony growths on the agar were counted and recorded.

\subsubsection{Total Mesophilic Fungal Counts}

10-fold serial dilution of the water was made using the method already described above. Then $0.1 \mathrm{ml}$ aliquot from 1 5 dilution plated on each plat containing already solidified Sabauroud dextrose agar medium. The water was spread evenly on the surface of the plate using a sterile swab stick and the plate allowed to dry and then incubated at $25{ }^{0} \mathrm{C}$ for 48 hours. The number of colonies growth on the plates was counted after the specified period of incubation. The number of colonies on the plate was counted after incubation and recorded as colony forming unit per $\mathrm{ml}$

\section{$(\mathrm{CFU} / \mathrm{ml})=\underline{\text { No of colonies } \times \text { dilution factor }}$}

$$
\text { Volume plated }
$$

\subsubsection{Most Probable Number (MPN)}

The water sample was thoroughly mixed by inverting the bottle several times. The cap was then removed and $50 \mathrm{mls}$ of water was added to the bottle containing $50 \mathrm{mls}$ of MarConkey broth (double strength), using a $10 \mathrm{mls}$ syringe, 10 mls of water as added to each of the five bottles containing $10 \mathrm{mls}$ of MarConkey broth (double strength). Also, $1 \mathrm{ml}$ of the water was added into each of the 5 bottles containing $5 \mathrm{mls}$ of MarConkey broth (single strength). For the

$$
\begin{aligned}
& \text { www.ijtrs.com } \\
& \text { www.ijtrs.org }
\end{aligned}
$$






International Journal of Technical Research \& Science

treated water sample, $50 \mathrm{mls}$ of water was added to the bottle containing $50 \mathrm{mls}$ of MarConkey broth (double strenght 0 and $10 \mathrm{mls}$ of water placed into each of the 5 bottles containing $10 \mathrm{mls}$ of MarConkey broth (double strength). The inoculated broths were then incubated at $44{ }^{0} \mathrm{C}$ for 24 hours with the bottles loosely caped. After the incubation period, the results were read and recorded using Cheesbrough (2000) standards.

The Pour Plate Count method was used for the total coliforms, faecal coliforms and E. Coli. $100 \mathrm{ml}$ of each water sample was measured into a sterilized petri dish. For total coliform and faecal coliform, $10 \mathrm{ml}$ of sterilized nutrient agar was added. For the E.Coli determination, $10 \mathrm{ml}$ of EC broth was added to $100 \mathrm{ml}$ of each water sample. It was then swirled to mix up and allowed to settle for about 10 minutes. It was then incubated at $37{ }^{0} \mathrm{C}$ for total coliforms and $44{ }^{\circ} \mathrm{C}$ for faecal coliforms and E. Coli. for 24 hours. After the 24 hours, growth was counted with colony counter. Pure colonies obtained by streaking on nutrient agar plates were subjected to some biochemical tests and further characterized by using Bergey's Manual of Determinative Bacteriology (Sneath, 1986).

\subsubsection{Health data}

Prevalence of water- borne diseases in the study area was investigated by visiting the State government health centre and one private clinic in Ijero-Ekiti where cases of water-borne diseases were documented. These were used to make preliminary inference of health impact of well water contamination by pit latrines. In the study area, the primary water sources were identified by speaking with the head of household and/or healthcare workers. The primary water source identified by majority of the people was hand dug wells. We considered the primary water sources and complaints of diarrhoea and other water related diseases in the health centre and private clinic.

\subsection{Statistical Analyses}

Statistical analysis of the results was done using Microsoft Excel and one-way randomised analysis of variance (ANOVA). The means was compared by L.S.D. at 0.05 level of significance. The least significant difference (P < $0.05)$ of data is reported.

\subsection{RESULTS AND DISCUSSION}

\subsection{Well Characteristics}

Characteristics of sampled well in the study area have been presented in Table 3.1. The survey assesses onsite sanitation systems leach contaminants as it affects groundwater. Table 3.1 also shows that the distance between hand dug wells and the latrines. The well characteristics of each well are also provided in the table alongside the environmental conditions.

Table-3.1 Distance of Dug Wells from Pit latrines and Environmental Conditions

\begin{tabular}{|l|l|l|l|l|}
\hline $\begin{array}{c}\text { Well } \\
\text { code }\end{array}$ & \multicolumn{1}{|c|}{ Location } & $\begin{array}{c}\text { Distance from } \\
\text { Latrine }\end{array}$ & \multicolumn{1}{|c|}{ Well Characteristics } & $\begin{array}{c}\text { Location of well (in } \\
\text { relation to land) }\end{array}$ \\
\hline A & Igbamitoro & 26.5 & $\begin{array}{l}\text { Well covered with metallic lid, inside } \\
\text { lined with concrete surroundings paved } \\
\text { and multiple receptacles used. }\end{array}$ & Downslope \\
\hline B & Igbamitoro & 17.8 & $\begin{array}{l}\text { Well not covered with metallic lid, } \\
\text { inside lined with concrete. }\end{array}$ & Flat land \\
\hline C & Igbamitoro & 8.3 & $\begin{array}{l}\text { Well covered with metallic lid, inside } \\
\text { lined with concrete surroundings paved } \\
\text { and multiple receptacles used. Multiple } \\
\text { toilet facilities }\end{array}$ & Flat land \\
\hline D & Igbo Oloko & 19.3 & $\begin{array}{l}\text { Well covered with metallic lid, inside } \\
\text { lined. Multiple receptacles used. }\end{array}$ & Downslope \\
\hline E & Igbo Oloko & 18.6 & $\begin{array}{l}\text { Well uncovered, inside lined. Multiple } \\
\text { receptacles used. Close to refuse dump }\end{array}$ & Flatland \\
\hline F & Olami & 5.1 & $\begin{array}{l}\text { Well uncovered, inside not lined. } \\
\text { Multiple receptacles used. Close to } \\
\text { bathroom }\end{array}$ & Flatland \\
\hline
\end{tabular}

\subsection{Physicochemical Parameters}

The physicochemical characteristics of the collected water samples are presented in Table 3.2 and Table 3.3. The temperature of the water samples ranged from $26.1 \pm 0.09$ to $27.5 \pm 0.06{ }^{0} \mathrm{C}$ with an average value of $26.65 \pm 0.12{ }^{0} \mathrm{C}$ with well $\mathrm{C}$ having the highest temperature. The colour of the water ranged from $2.6 \pm 0.17$ to $4.63 \pm 0.03$ with an average value of $3.83 \pm 0.17$ with well $F$ having the highest value. The turbidity of the water ranged from $7.4 \pm 0.05$ 


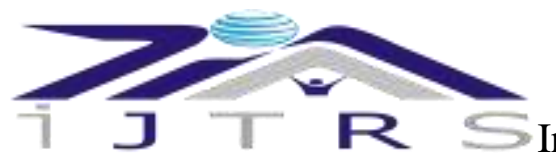

\section{International Journal of Technical Research \& Science}

to $18.9 \pm 0.15$ with an average value of $13.7 \pm 1.12 \mathrm{NTU}$ with well $\mathrm{C}$ having the highest value. The conductivity of the water ranged from $305 \pm 2.03$ to $705 \pm 3.07$ with an average value of $547.1 \pm 31.5 \mu \mathrm{S} / \mathbf{c m}$ with well $\mathrm{C}$ having the highest value. The total dissolved solids of the water ranged from $16.6 \pm 0.12$ to $57.2 \pm 1.48$ with an average value of $37.75 \pm 3.29 \mathrm{Mg} / \mathrm{L}$ with well $\mathrm{B}$ having the highest value. The alkalinity of the water ranged from from $20.5 \pm$ 0.43 to $28.58 \pm 0.24$ with an average value of $25.8 \pm 0.69 \mathrm{Mg} / \mathrm{L}$ with well A having the highest value. The total dissolved oxygen of the water ranged from $2.77 \pm 0.15$ to $4.5 \pm 0.07$ with an average value of $3.49 \pm 0.14 \mathrm{Mg} / \mathrm{L}$ with well A having the highest value. The chloride level of the water ranged from $93.9 \pm 3.27$ to $210.0 \pm 8.0$ with an average value of $148.4 \pm 10.4 \mathrm{Mg} / \mathrm{L}$ with well $\mathrm{E}$ having the highest value. The total hardness of the water ranged from $105.1 \pm 1.5$ to $229.0 \pm 15.91$ with an average value of $163.9 \pm 9.88 \mathrm{Mg} / \mathrm{L}$ with well $\mathrm{C}$ having the highest value. The total calcium hardness of the water ranged from $90.25 \pm 1.75$ to $97.6 \pm 0.26$ with an average value of $91.5 \pm$ $1.56 \mathrm{Mg} / \mathrm{L}$ with well A having the highest value. Statistical analysis showed highly significant differences $(\mathrm{P}<0.05)$ between all the above named parameters.

Other physicochemical and nutritional characteristics of the collected water samples are presented in Table 3.3. The nitrite level of the water ranged from $0.021 \pm 0.0003$ to $0.35 \pm 0.008$ with an average value of $0.107 \pm 0.04 \mathrm{Mg} / \mathrm{L}$ with well $\mathrm{E}$ having the highest value. The nitrate level of the water ranged from $4.7 \pm 0.13$ to $10.36 \pm 0.35$ with an average value of $6.99 \pm 0.64 \mathrm{Mg} / \mathrm{L}$ with well $\mathrm{E}$ having the highest value. The phosphate level of the water ranged from $0.21 \pm 0.006$ to $0.69 \pm 0.01$ with an average value of $0.40 \pm 0.04 \mathrm{Mg} / \mathrm{L}$ with well $\mathrm{E}$ having the highest value. The Ammonia level of the water ranged from $0.18 \pm 0.01$ to $0.73 \pm 0.03$ with an average value of $0.34 \pm 0.05 \mathrm{Mg} / \mathrm{L}$ with well $\mathrm{C}$ having the highest value. The Iron level of the water ranged from $0.13 \pm 0.009$ to $0.24 \pm 0.04$ with an average value of $0.17 \pm 0.011 \mathrm{Mg} / \mathrm{L}$ with well $\mathrm{F}$ having the highest value. The $\mathrm{pH}$ of the water ranged from $6.72 \pm$ 0.08 to $7.16 \pm 0.09$ with an average value of $6.9 \pm 0.04 \mathrm{Mg} / \mathrm{L}$ with well $\mathrm{E}$ having the highest value. Statistical analysis showed highly significant differences $(\mathrm{P}<0.05)$ between all the above named parameters.

Table-3.2 Physicochemical Properties of Well Samples

\begin{tabular}{|c|c|c|c|c|c|c|c|c|c|c|}
\hline Wells & $\begin{array}{l}\text { Temperature } \\
{ }^{0} \mathrm{C}\end{array}$ & Colour & $\begin{array}{l}\text { Turbidity } \\
\text { (NTU) }\end{array}$ & $\begin{array}{l}\text { Conductivity } \\
(\mu \mathrm{S} / \mathrm{cm})\end{array}$ & \begin{tabular}{|l|} 
Total \\
dissolved \\
solids \\
$(\mathrm{Mg} / \mathrm{L}$
\end{tabular} & $\begin{array}{l}\text { Alkalinity } \\
(\mathrm{Mg} / \mathrm{L} \\
\left.\mathrm{CaCO}_{3}\right)\end{array}$ & \begin{tabular}{|l} 
Total \\
dissolved \\
oxygen \\
$(\mathrm{Mg} / \mathrm{L})$
\end{tabular} & $\begin{array}{l}\text { Chloride } \\
(\mathrm{Mg} / \mathrm{L})\end{array}$ & $\begin{array}{l}\text { Total } \\
\text { hardness } \\
(\mathrm{Mg} / \mathrm{L})\end{array}$ & $\begin{array}{l}\text { Calcium } \\
\text { hardness } \\
(\mathrm{Mg} / \mathrm{L})\end{array}$ \\
\hline $\mathbf{A}$ & $26.4 \pm 0.35$ & $2.6 \pm 0.17$ & $7.4 \pm 0.05$ & $305 \pm 2.03$ & $16.6 \pm 0.12$ & $28.6 \pm 0.24$ & $4.5 \pm 0.07$ & $93.9 \pm 3.27$ & $105.1 \pm 1.5$ & $97.6 \pm 026$ \\
\hline B & $26.7 \pm 0.18$ & $3.4 \pm 0.12$ & $10.04 \pm 0.29$ & $476 \pm 1.15$ & $27.8 \pm 0.79$ & $26.1 \pm 0.21$ & $3.7 \pm 0.16$ & $105.5 \pm 3.77$ & $137 \pm 9.84$ & $94.4 \pm 0.47$ \\
\hline $\bar{C}$ & $27.5 \pm 0.06$ & $4.07 \pm 0.09$ & $20.4 \pm 0.09$ & $564 \pm 2.41$ & $57.2 \pm 1.48$ & $20.5 \pm 0.43$ & $3.04 \pm 0.05$ & $165 \pm 2.33$ & $229 \pm 15.9$ & $90.25 \pm 1.75$ \\
\hline D & $26.4 \pm 0.35$ & $3.83 \pm 0.07$ & $11.84 \pm 0.17$ & $644 \pm 1.18$ & $50.4 \pm 0.33$ & $24.03 \pm 0.3$ & $3.21 \pm 0.06$ & $188 \pm 3.28$ & $189 \pm 4.36$ & $78.5 \pm 0.45$ \\
\hline $\mathbf{E}$ & $26.1 \pm 0.09$ & $4.5 \pm 0.11$ & $13.74 \pm 0.44$ & $587 \pm 6.36$ & $35.9 \pm 1.71$ & $27.7 \pm 0.15$ & $2.77 \pm 0.15$ & $210 \pm 8.0$ & $165.7 \pm 1.76$ & $93.1 \pm 1.75$ \\
\hline $\mathbf{F}$ & $26.7 \pm 0.09$ & $4.63 \pm 0.03$ & $18.9 \pm 0.15$ & $705 \pm 3.07$ & $38.7 \pm 0.12$ & $27.9 \pm 0.06$ & $3.7 \pm 0.11$ & $127 \pm 3.05$ & $156 \pm 2.18$ & $95.17 \pm 1.39$ \\
\hline Mean & $26.65 \pm 0.12$ & $3.83 \pm 0.17$ & $13.7 \pm 1.12$ & $547 \pm 31.5$ & $37.75 \pm 3.29$ & $25.8 \pm 0.69$ & $3.49 \pm 0.14$ & $148.4 \pm 10.4$ & $163.9 \pm 9.88$ & $91.5 \pm 1.56$ \\
\hline LSD & 0.63 & 0.36 & 0.61 & 35.06 & 2.82 & 0.22 & 0.32 & 12.4 & 22.6 & 3.38 \\
\hline P level & * & $* * *$ & *** & $* * *$ & $* * *$ & *** & $* * *$ & $* * *$ & *** & $* * *$ \\
\hline \begin{tabular}{|l|} 
WHO \\
Standard
\end{tabular} & & $0-15$ & 5 & - & 1000 & & & 250 & 500 & - \\
\hline \begin{tabular}{|l|} 
EPA \\
Standard
\end{tabular} & & 15 & $0-5$ & F & 500 & & 500 & 500 & - & 65 \\
\hline
\end{tabular}

DOI Number: https://doi.org/10.30780/IJTRS.V04.I06.001

pg. 6

www.ijtrs.com

www.ijtrs.org 
ISSN No.: 2454- 2024 (online)

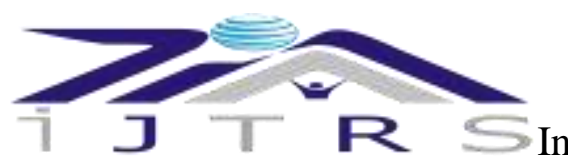

International Journal of Technical Research \& Science

Table-3.3 Physicochemical and Nutritional Properties of Well Samples

\begin{tabular}{|c|c|c|c|c|c|c|c|}
\hline Wells & $\begin{array}{l}\text { Nitrite } \\
(\mathrm{Mg} / \mathrm{L})\end{array}$ & $\begin{array}{l}\text { Nitrate } \\
(\mathrm{Mg} / \mathrm{L})\end{array}$ & $\begin{array}{l}\text { Phosphate } \\
\text { (Mg/L) }\end{array}$ & $\begin{array}{l}\text { Ammonia } \\
(\mathrm{Mg} / \mathrm{L})\end{array}$ & $\begin{array}{l}\text { Iron } \\
(\mathrm{Mg} / \mathrm{L})\end{array}$ & pH & Odour \\
\hline $\mathbf{A}$ & ND & $6.42 \pm 0.06$ & $0.32 \pm 0.017$ & $0.26 \pm 0.11$ & $0.17 \pm 0.01$ & $6.72 \pm 0.08$ & $\mathrm{U}$ \\
\hline B & $0.023 \pm 0.007$ & $4.7 \pm 0.13$ & $0.21 \pm 0.056$ & $0.18 \pm 0.01$ & $0.13 \pm 0.006$ & $7.0 \pm 0.06$ & $\mathrm{U}$ \\
\hline $\mathrm{C}$ & $0.021 \pm 0.0003$ & $9.7 \pm 0.11$ & $0.37 \pm 0.09$ & $0.73 \pm 0.03$ & $0.14 \pm 0.03$ & $6.84 \pm 0.07$ & $\mathrm{U}$ \\
\hline D & ND & $2.85 \pm 0.04$ & $0.46 \pm 0.03$ & $0.31 \pm 0.009$ & $0.21 \pm 0.009$ & $6.95 \pm 0.05$ & $\mathrm{U}$ \\
\hline $\mathbf{E}$ & $0.35 \pm 0.008$ & $10.36 \pm 0.35$ & $0.69 \pm 0.01$ & $0.24 \pm 0.07$ & $0.15 \pm 0.006$ & $7.16 \pm 0.09$ & $\mathrm{U}$ \\
\hline $\mathbf{F}$ & $0.25 \pm 0.11$ & $7.84 \pm 0.04$ & $0.37 \pm 0.008$ & $0.29 \pm 0.012$ & $0.24 \pm 0.014$ & $7.10 \pm 0.1$ & $\mathrm{U}$ \\
\hline Mean & $0.107 \pm 0.04$ & $6.99 \pm 0.64$ & $0.40 \pm 0.04$ & $0.34 \pm 0.05$ & $0.17 \pm 0.011$ & $6.9 \pm 0.04$ & \\
\hline LSD & 0.14 & 0.46 & 0.16 & 0.49 & 0.16 & 0.68 & \\
\hline P LEVEL & $* * *$ & $* * *$ & $* * *$ & $* * *$ & $* * *$ & **** & \\
\hline $\begin{array}{l}\text { WHO } \\
\text { Standard }\end{array}$ & 3 & 0.3 & 0.3 & 1.5 & 0.3 & $6.5-8.5$ & $\mathrm{U}$ \\
\hline $\begin{array}{l}\text { EPA } \\
\text { Standard }\end{array}$ & - & - & 0.3 & - & 0.3 & $6.5-8.5$ & $\mathrm{U}$ \\
\hline
\end{tabular}

\subsection{Bacteriological Analysis}

Results of the bacteriological analysis of the water sample are presented in Table 3.4. The total viable counts for all water samples were quite high ranging from $1.3 \times 10^{6} \mathrm{cfu} / \mathrm{ml}$ to $1.5 \times 10^{7} \mathrm{cfu} / \mathrm{ml}$. The most probable number (MPN) for presumptive total coliform count of the water samples ranged from $1.6 \times 10^{3}$ to $3.6 \times 10^{3}$ MPN per $100 \mathrm{ml}$. Wells $\mathrm{B}, \mathrm{C}, \mathrm{D}, \mathrm{E}$ and $\mathrm{F}$ had total coliform count greater than 1,800MPN per $100 \mathrm{ml}$ while sample A had the lowest total coliform count of 1,600MPN per 100ml. (Table 3.4).

Vibrio cholerae count of water samples, $\mathrm{C}$ and $\mathrm{F}$ ranged from $2.8 \times 10^{3} \mathrm{cfu} / \mathrm{ml}$ to $5.3 \times 10^{3} \mathrm{cfu} / \mathrm{ml}$ and sample $\mathrm{C}$ having the lowest of $2.8 \times 10^{3} \mathrm{cfu} / \mathrm{ml}$ while samples A, B, D and E showed no growth of Vibrio Sp. (Table 3.4). Salmonella and Shigella counts for samples C and F ranged from $5.2 \times 10^{3} \mathrm{cfu} / \mathrm{ml}$ to $2.8 \times 10^{4} \mathrm{cfu} / \mathrm{ml}$. Sample F has the highest Salmonella- shigella count of $2.8 \times 10^{4} \mathrm{cfu} / \mathrm{ml}$ (Table 3.4). The bacteria isolated from water samples in this work included Escherichia coli, Enterobacter aerogenes, Pseudomonas spp, Staphylococcus aureus, Salmonella typhosa, Shigella spp, Vibrio cholerae, Proteus spp, Klebsiella spp. with Salmonella, Shigella and V. cholerae not isolated from the wells A,B, D,E samples. The level of prevalence of the bacterial isolates are presented in Table 3.5 .

\subsection{Health Data}

Table 3.6 revealed that $83 \%$ of the two health centres visited reported high cases of typhoid fever among people below age 20 years. Gastro-enteritis and diarrhoea and were more prevalent at age 10 and below than all other age groups.

Table-3.4 Bacteriological Analysis of Water

\begin{tabular}{|l|l|l|l|l|l|}
\hline Well Code & $\begin{array}{l}\text { Distance from } \\
\text { latrine }\end{array}$ & $\begin{array}{l}\text { Total } \\
\text { Heterotrophic } \\
\text { count (cfu/ml) }\end{array}$ & $\begin{array}{l}\text { Total coliform } \\
\text { count (MPN/100 } \\
\text { ml) }\end{array}$ & $\begin{array}{l}\text { Salmonella } \\
\text { Shigella count } \\
\text { (cfu/ml) }\end{array}$ & $\begin{array}{l}\text { Vibrio } \\
\text { cholera count } \\
\text { (cfu/ml) }\end{array}$ \\
\hline A & 26.5 & $1.3 \times 10^{6}$ & $1.6 \times 10^{3}$ & $\mathrm{ND}$ & $\mathrm{ND}$ \\
\hline
\end{tabular}

DOI Number: https://doi.org/10.30780/IJTRS.V04.I06.001

pg. 7

www.ijtrs.com

www.ijtrs.org

Paper Id: IJTRS-V4-I3-003 


\begin{tabular}{|c|c|c|c|c|c|}
\hline B & 17.8 & $5.6 \times 10^{6}$ & $2.3 \times 10^{3}$ & ND & ND \\
\hline $\mathrm{C}$ & 8.3 & $6.3 \times 10^{6}$ & $3.1 \times 10^{3}$ & $2.8 \times 10^{3}$ & $5.2 \times 10^{3}$ \\
\hline D & 19.8 & $2.31 \times 10^{6}$ & $2.0 \times 10^{3}$ & ND & ND \\
\hline $\mathbf{E}$ & 18.6 & $4.4 \times 10^{6}$ & $2.5 \times 10^{3}$ & ND & ND \\
\hline $\mathbf{F}$ & 5.1 & $1.5 \times 10^{7}$ & $3.6 \times 10^{3}$ & $6.3 \times 10^{3}$ & $2.8 \times 10^{4}$ \\
\hline $\begin{array}{l}\text { WHO } \\
\text { Standard }\end{array}$ & $1.0 \times 10^{2}$ & Zero per $100 \mathrm{ml}$ & Zero & Zero & \\
\hline $\begin{array}{l}\text { EPA } \\
\text { Standard }\end{array}$ & $1.0 \times 10^{2}$ & Zero & Zero & Zero & \\
\hline
\end{tabular}

$\mathrm{ND}=$ No Detectable Count

Table-3.5 Microbial Isolates from Water Samples

\begin{tabular}{|c|c|c|c|c|c|c|}
\hline \multirow[t]{2}{*}{ Microoganisms } & \multicolumn{6}{|c|}{ WELLS } \\
\hline & WELL A & WELL B & WELL C & WELL D & WELL E & WELL F \\
\hline Pseudomonas sp & + & + & + & + & + & + \\
\hline E. coli & + & + & + & + & + & + \\
\hline $\begin{array}{l}\text { Enterobacter } \\
\text { aerogenes }\end{array}$ & + & + & + & + & + & + \\
\hline $\begin{array}{l}\text { Staphylococcus } \\
\text { aureus }\end{array}$ & + & + & + & + & + & + \\
\hline Salmonella typhi & - & - & + & - & - & + \\
\hline Vibrio cholera & - & - & + & - & - & + \\
\hline Proteus sp & + & + & + & + & + & + \\
\hline Klebsiella sp & + & + & + & + & + & + \\
\hline
\end{tabular}

+=Present, - =Absent

Table-3.6 Prevalence of Water Borne Diseases in Health Centers and Clinics

\begin{tabular}{|c|c|c|c|c|}
\hline \multicolumn{5}{|c|}{ State General Hospital Ijero-Ekiti } \\
\hline $\mathrm{S} / \mathrm{N}$ & Age & Typhoid Fever & Diarrhoea & Gastro-enteritis fever \\
\hline 1 & $0-10$ & 78 & 165 & 26 \\
\hline 2 & $11-20$ & 59 & 6 & 4 \\
\hline 3 & $21-40$ & 120 & 26 & 13 \\
\hline 4 & $41-60$ & 59 & 13 & Nil \\
\hline 5 & 61-above & 19 & 7 & Nil \\
\hline & Total & 335 & 217 & 39 \\
\hline \multicolumn{5}{|c|}{ Olusegun Hospital Ijero-Ekiti } \\
\hline $\mathrm{S} / \mathrm{N}$ & Age & Typhoid Fever & Diarrhoea & Gastro-enteritis fever \\
\hline 1 & $0-10$ & 24 & 50 & 11 \\
\hline 2 & $11-20$ & 19 & 17 & 4 \\
\hline
\end{tabular}

DOI Number: https://doi.org/10.30780/IJTRS.V04.I06.001

pg. 8

WWW.ijtrs.com

www.ijtrs.org

Paper Id: IJTRS-V4-I3-003 


\begin{tabular}{|l|l|l|l|l|}
\hline $\mathbf{3}$ & $21-40$ & 29 & 8 & 7 \\
\hline $\mathbf{4}$ & $41-60$ & 7 & Nil & 2 \\
\hline $\mathbf{5}$ & 61 -above & 6 & 5 & 3 \\
\hline & Total & $\mathbf{8 5}$ & $\mathbf{8 0}$ & $\mathbf{2 7}$ \\
\hline
\end{tabular}

\section{DISCUSSION}

\subsection{Sanitation Survey}

The study revealed that the dug-wells were sited between 10.3 and 27.2 metres from nearby pit latrines. This indicates that all the dug-wells were sited closer than the 30 metres minimum separation distance recommended by the Nigeria Water and Sanitation Board for drinking water supply dug-wells. This exposes the dug-wells to high risk of bacteriological contamination through inflow and seepage of faecal matter from the pit latrines. Also, many of the dug-wells did not have cover slaps and, in some cases, the inner perimeters of the wells were not lined with impermeable materials such as concrete. These, coupled with the poor sanitation around the majority of the dugwells put them at high risk of various forms of contamination. The use of multiple receptacles (rubber tubes and aluminium buckets) with various degrees of hygiene further exposes the dug-wells to contamination.

\subsection{Physico-Chemical Parameters}

\subsubsection{The $\mathrm{pH}$}

The results of the physico-chemical analysis of the water samples from the 6 dugwells show that the $\mathrm{pH}$ of the water samples ranged from 6.72 to 7.16 . The measured $\mathrm{pH}$ values indicate that all the 16 dug-wells had values that were within the EPA recommended range of 6.5-8.5 for drinking water, and did not appear to pose any problem to the water.

\subsubsection{Turbidity}

Water becomes turbid when substances like silt, clay, colloids and organic matter are present. Mean Turbidity ranged from 7.4 to 20.4 NTU in the water samples. The EPA guideline limit for turbidity for drinking water supplies is $5 \mathrm{NTU}$. The values recorded for the samples exceeded this limit except in dug-well $\mathrm{W} 4$ where the mean value was within this limit. Well A in the Igbo oloko sampling site is a dug-well that was covered with a metallic lid and the inside walls were lined with concrete material. Also, the immediate surroundings were paved with concrete. These conditions might have combined to reduce the inflow of runoff or infiltrated water into the dug-well, hence the low value of turbidity. The generally high turbidity values could be caused by surface run-off and the fact that most of the dug wells were not lined, paved or covered. The soil becomes loose and disturbed during water withdrawal when dugwells are unlined, unpaved or uncovered (Mishra et al., 2009).

It was also observed that the rope of the receptacle for water withdrawal was usually left in the dirty water around the dug-wells after water withdrawal and reintroduced into the dug-wells during the next withdrawal. Duncan (1996) explains that high turbidity may be caused when light is blocked by large amounts of silt and microorganisms in water. Moreover, bacteria, viruses and parasites such as giardia and cryptosporidium can attach themselves to the suspended particles in turbid waters (Metcalf and Eddy, 2003). Turbidity is also considered as surrogate microbiological parameter because it is closely linked to the microbiological safety of drinking water (FPTSDW, 2001). Turbidity can indicate that water may be contaminated with pathogens presenting human health concerns (Olson, 2004).

\subsubsection{Nitrate and Nitrite}

The 6 dug-wells sampled from the four suburbs recorded mean nitrate and nitrite concentrations of 2.85-10.36 mg/l and $0.02-0.35 \mathrm{mg} / \mathrm{l}$. All the examined dug-wells had nitrate and nitrite concentrations that were within the EPA acceptable limit $50 \mathrm{mg} / \mathrm{l}$ and $3 \mathrm{mg} / \mathrm{l}$, respectively. Although the concentrations were generally low (Table 3.3), the relatively high levels in some of the dug-wells suggest other anthropogenic influence such as transport of organic matter from the pit latrines. The low levels of nitrate and nitrite in the dug-wells might be due to the fact that agricultural activities were not carried out at the sampling sites. Suthar et al., (2009) had strongly suggested intensive agriculture and heavy use of $\mathrm{N}$-fertilizer to be a major enrichment of nitrate in groundwater. This is also in agreement with an observation in a (WHO, 2008) drinking water quality report which concluded that the nitrate concentration in groundwater and surface water is normally low but can reach higher levels as a result of leaching or run-off from agricultural land or contamination from human or animal waste as a consequence of the oxidation of ammonia and similar sources. The sources of nitrate and nitrite to groundwater also include natural geologic deposit,

$$
\begin{aligned}
& \text { www.ijtrs.com } \\
& \text { www.ijtrs.org }
\end{aligned}
$$




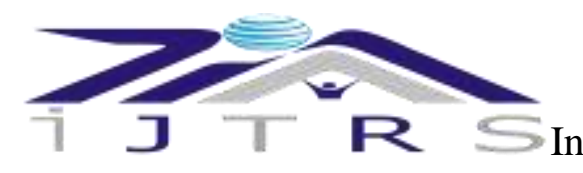

International Journal of Technical Research \& Science

mineralization of soil organic nitrogen, intense use of fertilizer, and human and animal sewage (Hallerg and Keeney, 1993).

\subsubsection{Phosphate}

The mean concentrations of phosphate recorded in the study were very low ( 0.21 to $0.69 \mathrm{mg} / \mathrm{l})$, and were within the maximum allowable limit of $400 \mathrm{mg} / \mathrm{l}$ recommended by the EPA for drinking water. The low concentration of the phosphate in the dug-well water samples might be due to the geology of the area and confirms similar work done by (Adeyemo et al., 2008). The results also show that addition of nutrient from anthropogenic sources to the well water is minimal. Phosphate constitutes a very important pollution problem whenever it is found in significant amount. It promotes algae growth and / or microphytes, leading to the cyclic problem of eutrophication (Thriodore, 2004). It is established that high phosphorus concentration has no health implication except for its role in causing eutrophication of water bodies (WHO, 2004).

\subsubsection{Ammonia}

The mean concentration of ammonia recorded in all the 6 dug-wells ranged from 0.18 to $0.73 \mathrm{mg} / \mathrm{l}$. These were within the EPA standard of $1.5 \mathrm{mg} / \mathrm{l}$ for drinking water. The highest mean concentration of $0.81 \mathrm{mg} / 1 \mathrm{was}$ recorded in dugwell $\mathrm{C}$ sited 10.3 metres from the nearest pit Ammonia occurs naturally in groundwater because of leakage from agricultural land, animal keeping, sewage and metabolic processes in the ground (WHO, 2004). Ammonia is also released upon decomposition of proteinaceous matter and can be released into the atmosphere, used directly by microorganisms or converted into nitrite and nitrate (Liu, 1999). The presence of ammonia in the wells indicates possible bacterial, sewage and animal waste pollution (WHO, 2004).

\subsection{Bacteriological Parameters}

Heterotrophic count (HPC) measures a range of bacteria that are naturally present in the environment (EPA, 2002). The total bacterial counts in this study for all the water samples were generally high exceeding the limit of $1.0 \times 10^{2}$ $\mathrm{cfu} / \mathrm{ml}$ which is the standard limit of heterotrophic count for drinking water (EPA, 2002). The high total heterotrophic count is indicative of the presence of high organic and dissolved salts in the water. The primary sources of these bacteria in water are animal and human wastes. These sources of bacterial contamination include surface runoff, pasture, and other land areas where animal wastes are deposited. Additional sources include seepage or discharge from septic tanks, sewage treatment facilities and natural soil /plant bacteria (EPA, 2002). These contaminants are reflected in the highest bacterial load obtained in this study for the river and Sokori stream water samples. The microbial count was higher in well water close to refuse disposal site as compared to well water far away but both microbial count are lower than that of river water. Generally, underground water is believed to be the purest known (Gordan and John, 1996) because of the purification properties of the soil however, it can also be contaminated. Groundwater are found to be contaminated due to improper construction, shallowness, animal wastes, proximity to toilet facilities, sewage, refuse dump sites, and various human activities around the well (Bitton, 1994). The presumed reason for contamination of well water accounts for why the microbial load of well water close to refuse disposal site have higher microbial count than the one far away from refuse disposal site. Environmental Protection Agency (EPA) establishes heterotrophic plate count as a primary standard, which are based on health considerations.

Accordingly, the total coliform count for all samples were exceedingly high the EPA maximum contamination level (MCL) for coliform bacteria in drinking water of zero total coliform per 100ml of water (EPA, 2003). The high coliform count obtained in the samples may be an indication that the water sources are faecally contaminated (EPA, 2003; Osuinde and Enuezie, 1999). None of the water samples complies with EPA standard for coliform in water. According to EPA standard, every water sample that has coliform must be analyzed for either fecal coliforms or E. coli (EPA, 2003) with a view to ascertaining contamination with human or animal waste and possibly pathogenic bacteria organism, such as Gardia and Cryptosporidium may be present (EPA, 2003).The high number of Salmonella, Shigella spp and Vibrio cholerae in stream and river samples is not in agreement with EPA water standard for consumption use which states that these pathogenic organism must not be present in water, because they are of public health significance, having been associated with gastrointestinal infections: diarrhoea, dysentery, typhoid fever and other form of infection (EPA, 2003). The non-detection of pathogen in the well water sample may be a reflection on the depth of the well among several other contributing risk factors. Other bacteria isolated from all water samples such as Staphylococcus aureus, Pseudomonas aeuruginosa, and proteus sp. Proteus spp are also of public health significance. Staphylococcus aureus is known to produce enterotoxin. Proteus spp belongs to the intestinal flora but is also widely distributed in soil and water (Schlegel, 2002). Enterobacter aerognes isolated from the water samples are examples of non-fecal coliforms and can be found in vegetation and soil which serves as sources by which the pathogens enters the water (Schlegel, 2002). The British Standard Institute (BSI, 1993) specified that counts greater than $10^{4}$ are considered unsatisfactory for Enterobacter spp.

DOI Number: https://doi.org/10.30780/IJTRS.V04.I06.001

$$
\begin{aligned}
& \text { www.ijtrs.com } \\
& \text { www.ijtrs.org }
\end{aligned}
$$




\section{T}

The presence of total coliforms, fecal coliform, E. coli, Salmonella spp, Shigella spp and Vibrio spp have been documented as national primary drinking water regulations (NPDWRs) or primary standards which protect public health by limiting the levels of contaminants in drinking water (EPA, 2002).

\subsection{Health Implications}

The study revealed high faecal contamination in the well water in Ijero-Ekiti which shows high possibility of the presence of disease pathogens. There are many cases of water-related diseases and infections reported in the health centre and private clinic visited during the study showing many people drank from contaminated water sources. E. coli O157:H7 a strains of E. coli bacteria have being identified to cause illness, such as hemorrhagic diarrhoea and haemolytic uremic syndrome HUS) which causes kidney failure, which could jeopardize the health of young children and anyone with a challenged immune system (Olsen et al., 2002) In this study, diarrhoea and gastroenteritis were more prevalent among children of school age 10 while many adults are down with typhoid fever. This has potential direct and indirect public health and economic impacts. Water-related diseases often affect peoples' productivity as illnesses related to poor sanitation have direct impact on household finances in terms of the financial expenditure to pay for medicines and primary healthcare as well as the loss of working days due to sickness (Norstrom et al., 2011). Hygiene promotion is widely acknowledged as one of the most cost effective public health interventions (Atenstaedt et al., 2010).

Therefore, it is essential that public health professionals work collaboratively to identify access and manage public health risks, and take action to communicate these risks effectively to all affected parties (Zilov, 2013).

\section{CONCLUSION}

It is evident that most hand-dug wells in the study area were contaminated with faecal matter that leached from nearby pit latrines, which has negative implication to achieving sustainable health. The hand-dug well water quality fell short of the WHO guidelines for drinking water quality and improved urban sanitation, promotion of hygienic behaviour can help reduce the risk of exposure to pathogens, and hazardous substances that could affect public health at all points of the sanitation system; and eventually contribute to the socio-economic development. There is the urgent need for the promotion of the delivery of sustainable water supply, sanitation and hygiene services by improving the water quality at the source through adequate protection of well water, treatment and provision of alternative sources such as improved pipe-borne water to the people. Sitting wells at higher elevations of at least 30 metres and the bottom of the pits should be at least 1.5 metres above the groundwater table.

The study revealed that all the physico-chemical parameters of water analyzed (except turbidity) from the various dug-wells fell within the EPA standards for drinking water. The high turbidity levels of the tested water make the water aesthetically unpleasant for human consumption. All the dug-wells from the areas tested positive to faecal coliform and E. Coli count in drinking water. The presence of faecal coliform and E. coli suggest that there is faecal contamination of the dug-wells from the pit latrines due to close proximity thus making the dug- wells unacceptable and not recommended as potable water for drinking.

Based on the results of this study, the Water and Sanitation Board in the local and State Government should ensure that the distance of pit latrines to hand dug-wells meet the recommended distance of 30 metres by Water and Sanitation Board. Government should ensure adequate and efficient public water supply through the provision of pipe-borne water.There should be the creation of awareness and education of residents on hand dugwell construction, citing and maintenance. Water from the dug-wells should be boiled before use and there should be proper general sanitation management practices by residents.

\section{REFERENCES}

[1] Adeyemo, O.K., Adedokun, O. A., Yusuf, R. K. and Adeleye, E. A. (2008). Seasonal Changes in Physicochemical Parameters and Nutrient load in river sediments in Ibadan City, Nigeria, Global NEST Journal, vol 10 No.3 pp: $326-336$.

[2] Amadi ES, Ayogu TE. (2005). Microbiology laboratory manual II. Cresco Printing and Publishers, Abakpa, Enugu 1, pp 40-55.

[3] American Public Health Association (APHA) American Water Works Association (AWWA) and Water Pollution Federation (WPCF) (1985). Standard Methods for the Examination of Water and Waste water, 16th Edition. Washington, D. C., PP. $1260-1268$.

[4] Ayanlaja, S. A., Kehinde-Philips, O. O., Ogunkola, F., Dada, B., Senjobi, B. (2005). Quality of water from hand dug wells, boreholes and streams in two localities in South Western Nigeria. Implication of the $4^{\text {th }}$ international groundwater quality conference, Waterloo, Canadian IAHS Publication, 47: 97-108.

[5] Bitton, G. (1994). Waste Water Microbiology. Gainesville, New York Wiley- Liss. 118p.

$$
\begin{aligned}
& \text { www.ijtrs.com } \\
& \text { www.ijtrs.org }
\end{aligned}
$$


[6] Cheesbrough M. (2000). District laboratory practice in tropical countries, part 2, Cambridge University Press, Cambridge, UK, pp 143-145.

[7] Drangert, J. O. and Cronin, A .A. (2004). Use and abuse of urban groundwater resource: Implication for a new management strategy. Hydrology Journal, 12(1): 94-102.

[8] Duncan, T. W. K. (1996). Water Supply and Health of Africans in Sofoluwe. University Press Plc, Ibadan. Federal-Provincial-Territorial Subcommittee on Drinking Water (FPTSDW), 2001.

[9] EPA, (2002). US Environment Protection Agency, Safe Drinking Water Act Ammendment http:// www. epa. gov/safe water $/ \mathrm{mcl}$. Html

[10]EPA, (2003). US Environmental Protection Agency Safe Drinking Water Act.

[11] Fewtrell, L., Pruss-Ustun, A., Bos, R., Gore, F. and Bartram, J. (2007). Water, sanitation and hygiene: quantifying the health impact at national and local levels in countries with incomplete water supply and sanitation coverage. WHO, Geneva.

[12] Gordan, M.; Fair and John, Gever, G. (1996). Water supply and Waste Removal in: Waste $\quad$ supply and Waste Removal In: Waste Engineering Vol. John Wiley and Sons pp 220-236.

[13] Hallberg, G. A. and Keeney, D. R. (1993): Sources of Nitrate to groundwater, pp. 300-301.

[14] Howard, G., Pedley, S., Barret, M., Nalubega, M., John, L. (2002). Contamination of shallow groundwater in Kampala, Uganda. Water Res 27(14): 3421-3429.

[15] Liu, D. (1999). Environmental Engineers Handbook. CRC press LLC. Florida, USA, Pp 539 - 546.

[16] Metcalf and Eddy, Inc. (2003). Wastewater Engineering Treatment and Reuse. McGraw - Hill, New York. 4th Edition, Pp 1, 10, 58, 69.

[17] Mishra, D., Mudgal, M., Khan, M. A., Padmakaran, P., Chakradhar, B. (2009). Assesement of Groundwater quality of Bhavnagar region (Gujarat). J. Scientific and Industrial Research, 68: 964-966.

[18] National Water Resources Institute (NWRI) (2001). Training Guide for Water Quality Testing and Control Course Code 1011, Kaduna, PP. 26 - 61.

[19] Norström, J. McConville, J. Parkinson, D. Saywell, R. Ingle.(2011) Sustainable Sanitation $\quad$ in Cities A Framework for Action. Sustainable Sanitation Alliance (SuSanA) \& International Forum on Urbanism (IFoU), Papiroz Publishing House, the Netherlands. Available at www.papiroz.com (Accessed 16th October 2013).

[20] Nsi, E. W. (2007). Basic Environmental Chemistry. The Return Press Ltd, PP. 126 - 151.

[21] Amadi, E.S and Ayogu T.E. (2005). Microbiology laboratory manual II. Cresco Printing and Publishers, Abakpa, Enugu 1, pp 40-55.

[22] Olsen,S.J, G. Miller, T. Breuer, M. Kennedy, C. Higgins and J. Walford et al.(2002). A Waterborne Outbreak of Escherichia coli O157:H7 Infections and Hemolytic Uremic Syndrome: Implications for Rural Water Systems. Emerging Infectious Diseases, 84: 370-375.

[23] Olson, E. (2004). Grading Drinking water in U.S cities what's on Tap? pp. 38-42.

[24] Osuinde. M.I. and Eneuzie, N.R. (1999). "Bacteriological analysis of ground water." NigeriaPriis-Ustun, A., Kay, Fewiel, L., Bartrain, J. (2004). Unsafe water, Sanitation and hygiene. In: Egzat, M., Lopez, A. D., Roger, A., Murray, C. J (eds). Comparative quatitative of health risks, Global and Regional Burden of disease attributed to selected major risk factors.

[25] Pritchard, M., Mkandawire, T. and Oneil, J. G. (2007). Biological, chemical and physical drinking water quality from shallow wells in Malawi: Physics and Chemistry of the earth 32(2007) 1167-1177.

[26] Schlegel, H.G. (2002). General Microbiology. 7th. ed. Cambridge. University Press. 480p.

[27] Self, J. R., and Waskom, R. M. (2008). Nitrate in Drinking Water. Colorado State University Extension.

[28] Thriodore, B. S. (2004). Interpreting Drinking Water Quality. Cook College, Rutgers University, New Brunswick.

[29] Trivedy, R. K. and Goel, P. K. (1986). Chemical and Biologica World Health Organization (WHO) (1985). Guidelines for Drinking Water Quality, PP. 1-2.

[30] UNICEF/WHO (2012). Progress on drinking water and sanitation: 2012 updates; US-EPA (1983). Methods for Chemical Analysis of Water and Wastes. US-EPA, EMSL, Cincinnati, EPA - 600/4, 79 -020.

[31] Xu, Y. and Usher, B. H. (2006). Issues of groundwater pollution in Africa. In Y,. Xu, and B. H., Usher, (Eds.). Groundwater Pollution in Africa, (pp.3-9). Leiden: Taylor and Francis Balkema.

[32] WHO (2008). Guidelines for Drinking Water Quality, 3rd ed. Vol.1. Incorporating the first and Second Addenda, WHO, Geneva (2008): ISBN 9789241547611.

[33]Zilov, E.A. (2013). Water resources and the sustainable development of humankind: International cooperation in the rational use of freshwater-lake resources: Conclusions from materials of foreign studies. Water Resources, 40(1):84-95. 